\title{
The Effect of Modification with Epoxy and Polyester Resins on Some Mechanical Properties of Pine and Chestnut Woods ${ }^{[*]}$
}

\author{
Hüseyin PELİT ${ }^{1 *} \quad$ Esra KASAR $^{1} \quad$ Abdullah SÖNMEZ $^{2}$ \\ ${ }^{1}$ Duzce University, Faculty of Technology, Department of Wood Products Industrial Engineering, Duzce, Turkey. \\ ${ }^{2}$ Gazi University, Faculty of Technology, Department of Wood Products Industrial Engineering, Ankara, Turkey. \\ *(D): https://orcid.org/0000-0002-5706-473X, $\quad$ (D): https://orcid.org/0000-0001-9337-9731, ID: https://orcid.org/0000-0001-5087-0563
}

How to cite: Pelit, H., Kasar, E. \& Sönmez, A. (2019). The Effect of Modification with Epoxy and Polyester Resins on Some Mechanical Properties of Pine and Chestnut Woods. Anatolian Env. and Anim. Sciences, 4(4), 621-626.

Atıf yapmak için: Pelit, H., Kasar, E. \& Sönmez, A. (2019). Çam ve Kestane Odunlarının Bazı Mekanik Özellikleri Üzerine Epoksi ve Polyester Reçineler İle Modifikasyonun Etkisi. Anadolu Çev. ve Hay. Dergisi, 4(4), 621-626.

Abstract: In this study, the effects of epoxy and polyester resin applications on some mechanical strength properties of scots pine (Pinus sylvestris L.) and chestnut (Castanea sativa) wood samples were investigated. Firstly, in the circular sawing machine, a different numbers of channels $(2+1$ and $3+2)$ were opened on the surfaces of wood samples. Then, these channels were filled with casting type epoxy and polyester resins. The density, modulus of rupture (MOR), modulus of elasticity (MOE), and compression strength parallel to the grain (CS) tests were performed on the samples. According to the results of the study, the density values of pine and chestnut samples increased by $25 \%$ and $42 \%$, respectively, depending on the number of channels after resin application. In addition, compared with epoxy resin applied samples, the density increase was higher in the polyester resin applied samples. After application of resins, a slight increase was observed in the MOR and MOE values of chestnut samples. However, CS values tend to decrease in these samples. In pine samples with resin applied, the strength properties (MOR, MOE and CS) decreased depending on the increase in the number of channels. Furthermore, the effect of the resin type on all strength properties of the samples was statistically insignificant.

Keywords: Epoxy resin, mechanical properties, polyester resin, wood material.

\section{Çam ve Kestane Odunlarının Bazı Mekanik Özellikleri Üzerine Epoksi ve Polyester Reçineler İle Modifikasyonun Etkisi}

Öz: Bu çalışmada, sarıçam (Pinus sylvestris L.) ve kestane (Castanea sativa) odunu örneklerinin bazı mekanik direnç özellikleri üzerine epoksi ve polyester reçine uygulamalarının etkisi incelenmiştir. Öncelikle daire testere makinesinde örneklere farklı sayılarda $(2+1$ ve 3+2) kanallar açılmıştır. Daha sonra bu kanallar döküm tipi epoksi ve polyester reçineler ile doldurulmuştur. Örneklerde meydana gelen değişiklikleri belirlemek için hava kurusu yoğunluk, eğilme direnci (ED), elastikiyet modülü (EM) ve liflere paralel basınç direnci (BD) testleri gerçekleştirilmiştir. Çalışmanın sonuçlarına göre, kanal sayısı artışına bağlı olarak reçine uygulamalarından sonra çam ve kestane örneklerin yoğunluk değerleri sırası ile \%25 ve \%42'ye kadar artmıştır. Ayrıca, epoksi reçineye göre polyester reçine uygulanmış örneklerde yoğunluk artış1 daha yüksektir. Kestane örneklerin ED ve EM direncinde reçine uygulama işlemlerinden sonra biraz artış gözlenmiştir. Ancak bu örneklerde BD direnci azalmıştır. Reçine uygulanmış olan çam örneklerde ise tüm mekanik direnç özellikleri (ED, EM ve BD) kanal sayısındaki artışa bağlı olarak azalmıştır. Ayrıca, mekanik direnç özellikler üzerinde reçine tipinin etkisi genel olarak önemsizdir. 


\section{INTRODUCTION}

Wood is a material used by mankind since the dawn of time due to its high-quality properties. Wood which used to be used as a basic material in the construction of houses is now being used in designing the living spaces. Wood is indispensable both for living spaces and for its healthy and durable structure.

The warm image of natural wood let it be widely used in interior spaces, which led to new ideas. Since the beginning of the 21 st century, interest in products such as wooden desks and tables has increased. When the products produced by natural wood are touched, they give the feeling of being just inside nature where the wood has been taken from. With concrete becoming more and more widespread, people's desire to get back to nature has motivated these designs to be even more involved in our life (Web-1). In recent years, products made from natural wood materials are very popular. Wood materials and various resins are generally used in combination in the manufacture of these products. Thus, very different types of designs are emerging and especially the aesthetic look is emphasized. In addition, with the use of resins, different wood defects can be removed. Many types of furniture and decoration elements are produced using natural wood. Some of these products are; table, coffee table, TV units, consoles, bookshelves, pendant lamps and wooden wall designs. In the production of these products, the most commonly used wood species are pine, maple, juniper, plane, walnut, oak, chestnut, mulberry, and ash. Epoxy and polyester resins are generally used to remove various wood defects (cracks, slits, knot fall, etc.) in furniture and decoration elements produced from natural wood. In addition, these resins are now often preferred for their aesthetic and decorative reasons, together with wood.

Epoxy resins can strongly adhere to many materials such as metal, plastic, glass, and wood (Bulmuş \& Pişkin, 2000; Şahmetlioğlu, 2000). In addition, it has many important properties such as high mechanical strength, chemical resistance, corrosion resistance, dimensional stability, wetting and filling ability of fiber reinforcements (Kaw, 2005; Chung, 2010). Epoxy resins are used in marine, automotive, aerospace and construction industries due to their superior properties. It is also widely used in many applications such as coatings, adhesives, insulation materials and composite materials (Güzel, 2016). Polyester resins have high resistance to chemical and environmental influences. They also have high dimensional stability and low viscosity. They are less costly and harden faster than epoxy resins (Sezgin, 2018) but have higher shrinkage ratios after curing (Seyhan et al., 2007). Polyester resins are used in automotive industry, building constructions, marine applications and composite materials as a matrix. When compared to epoxy resin, their thermal, air and mechanical strength properties are low, so their use in high-performance composites is limited (Campbell, 2010; Sezgin, 2018).
The aim of this study is to determine the density and the mechanical strength properties of scots pine (Pinus sylvestris L.) and chestnut (Castanea sativa) woods modified with epoxy and polyester resins.

\section{MATERIAL and METHODS}

Wood material: In this study, scotch pine (Pinus sylvestris L.) and chestnut (Castanea sativa) woods were used. Wood materials were supplied by random selection method from a timber company in the Düzce city in Turkey. Attention was paid to ensure that no rot, knot, crack, color, or density differences were present in the samples (TS 2470, 1976). A sufficient number of experimental samples were prepared with $20 \times 20 \times 340 \mathrm{~mm}$ (tangential direction $\times$ radial direction $\times$ longitudinal direction) dimensions from the sapwood parts of the wood materials which have air-dry moisture. Thereafter, a different number of channels $(2+1$ and $3+2$ ) were opened with $2.4 \mathrm{~mm}$ wide and $7 \mathrm{~mm}$ depth to the samples subjected to be treated by resin, at corresponding pairs of surfaces (tangential section) using a circular saw machine (Figure 1).

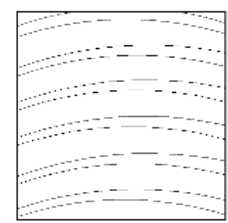

Control

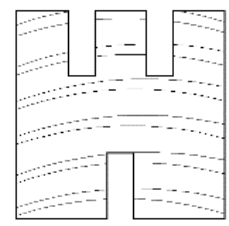

$2+1$ canal

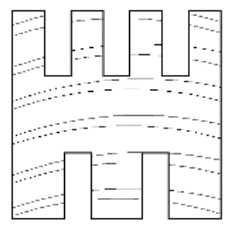

$3+2$ cana
Figure 1. Appearance of cross sections of the samples.

After opening channels, samples remained at a temperature of $20 \pm 2{ }^{\circ} \mathrm{C}$ and relative humidity of $65 \pm 3 \%$ until they reached a stable weight (TS 2471, 1976).

Resin Application: In the treatment of samples casting type epoxy and polyester resins were used. Some properties of these resins are given in Table 1.

Table 1. Properties of resins

\begin{tabular}{lccccc}
\hline $\begin{array}{l}\text { Resin } \\
\text { type }\end{array}$ & $\begin{array}{c}\text { Viscosity } \\
(\mathbf{c p l})\end{array}$ & $\begin{array}{c}\text { Density } \\
(\mathbf{g} / \mathbf{c m} \mathbf{3})\left(\mathbf{2 0}{ }^{\circ} \mathbf{C}\right)\end{array}$ & $\begin{array}{c}\text { Gelling time } \\
(\mathbf{m i n} .)\end{array}$ & $\begin{array}{c}\text { Elongation at } \\
\text { break } \mathbf{( \% )}\end{array}$ & $\begin{array}{c}\text { Hardness } \\
(\text { Barkol })\end{array}$ \\
\hline Epoxy & 156 & 1.2 & $110-130$ & 1.0 & 66 \\
\hline Polyester & 450 & 1.6 & 8 & 2.3 & 45 \\
\hline
\end{tabular}

Before the resin processing, cross sections of the experimental samples were closed using paper tape to prevent resin leakage. When the resins were prepared, the hardener and/or accelerator mixture ratios were carried out in accordance with the manufacturers' recommendations. The channels opening into the samples were filled with the resin using an injector with the appropriate tip clearance under room conditions $\left(20 \pm 2{ }^{\circ} \mathrm{C}\right)$ (Figure 2$)$. 


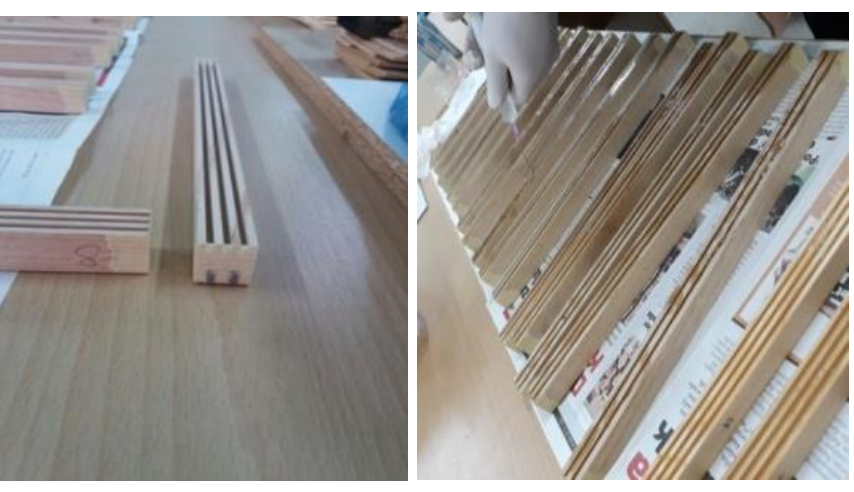

Figure 2. Application of resins to wood samples.

After filling the channels on the first surface with resin, the samples were left on the counter with a balanced scale for 48 hours. Then resin filling was performed on the channels on the second surface. The samples, in this case, were kept for about three weeks. After the resins had been thoroughly dried, the samples were passed through a calibrating sanding machine to remove excess resin on the surfaces. After, samples remained in a conditioning cabin (RH $65 \pm 3 \%$ and $20 \pm 2^{\circ} \mathrm{C}$ ) until they reached a stable weight (TS 2471, 1976). Then, samples were cut into smaller samples according to the specified test standard. The test samples were prepared in the number as to eight repetitions $(n=8)$ for each variable.

Determination of Density: Air-dry density of the samples were determined according to TS 2472, (1976). The mass of each sample $\left(M_{12}\right)$ was measured on an analytical balance, with a sensitivity of $\pm 0.01 \mathrm{~g}$. Dimensions (length, width, thickness) were measured with a vernier caliper having $\pm 0.01 \mathrm{~mm}$ sensitivity, and volumes $\left(V_{12}\right)$ were determined. The air-dry density $\left(\delta_{12}\right)$ was calculated using Eqs. 1.

$\delta_{12}=M_{12} / V_{12} \quad\left(\mathrm{~g} / \mathrm{cm}^{3}\right)$

Determination of MOR, MOE and CS Strength: Modulus of rupture (MOR) (or bending strength) and modulus of elasticity (MOE) of the samples were determined according to TS 2474, (1976). The MOR and MOE values were calculated by using following Eqs. 2 and 3.

$$
\begin{array}{ll}
M O R=3 P_{\max } L / 2 b d^{2} & \left(\mathrm{~N} / \mathrm{mm}^{2}\right) \\
M O E=P L^{3} / 4 b d^{3} \Delta & \left(\mathrm{N} / \mathrm{mm}^{2}\right)
\end{array}
$$

Where $P_{\max }$ is the maximum load when the sample is broken $(\mathrm{N}), L$ is the supporting span $(\mathrm{mm}), b$ is the width of the samples $(\mathrm{mm}), d$ is the thickness (depth) of the samples (mm), $\Delta$ deflection at mid-length below the proportion deflection limit (mm), and $P$ is the load in $\mathrm{N}$ within the proportional deflection $(\mathrm{N})$.

Compression strength parallel to the grain $(C S)$ of the samples were determined according to ISO/DIS 13061-
17, (2015). The CS values were calculated by using following Eqs. 4.

$C S=P_{\max } / b d \quad\left(\mathrm{~N} / \mathrm{mm}^{2}\right)$

where $P_{\max }$ is the maximum load applied to the samples $(\mathrm{N}), b$ is the width of the samples $(\mathrm{mm}), d$ is the thickness of the samples (mm).

Statistical Analysis: The MSTAT-C software program was used for the evaluation of data. ANOVA (analysis of variance) tests were performed to determine the effect of resin type and number of channel on the density and mechanical properties (MOR, MOE and CS) of scotch pine and chestnut woods at the 0.05 significance level. Duncan's tests were conducted for comparisons of the means of the density and mechanical strength values of the wood samples.

\section{RESULTS and DISCUSSION}

Arithmetic means of density, modulus of rupture (MOR), modulus of elasticity (MOE), and compression strength parallel to the grain (CS) values of the wood samples are given in Table 2. Additionally, analysis of variance results of density, MOR, MOE, and CS measurements from wood samples resin applied are shown in Table 3.

According to Table 3, the effects of resin type and number of channel factors on density in both wood species were found to be statistically significant. In addition, the effect of number of channel on MOR, MOE, and CS of the pine wood samples was significant, while the effect of the resin type was insignificant. On the other hand, both resin type and effect of number of channel on MOR, MOE, and CS of the chestnut wood samples were found to be insignificant $(P \leq 0.05)$. In the pine and chestnut woods, comparison results of the Duncan's tests conducted for the factors of resin type and number of channel are given in Table 4.

Regarding resin type, the highest density for both wood species was found to be in the samples applied polyester resin and the lowest was found in the samples applied epoxy resin (Table 4). It is shown in Table 1 that the polyester resin used in the work has a higher density than the epoxy resin. With respect to number of channel, the highest density was found to be in the $3+2$ channels opened samples, while the lowest was obtained in the control samples (Table 4). Depending on the increase in the number of channels, the density value of the samples also increased. In other words, the increase in the amount of resin applied to wood materials caused an increase in density. This can be explained by the fact that the densities of the resin filled in the opened channels are higher than the density of the wood materials. After resin application, density value of pine and chestnut samples increased up to $25 \%$ and $42 \%$ compared to control samples (Table 2). 
Table 2. Arithmetic means of the density, MOR, MOE and CS values.

\begin{tabular}{|c|c|c|c|c|c|c|}
\hline \multirow{2}{*}{ Wood species } & \multirow{2}{*}{ Resin type } & \multirow{2}{*}{$\begin{array}{c}\text { Number of } \\
\text { channel }\end{array}$} & \multicolumn{4}{|c|}{ Tests } \\
\hline & & & Density $\left(\mathrm{g} / \mathrm{cm}^{3}\right)$ & $\operatorname{MOR}\left(\mathrm{N} / \mathrm{mm}^{2}\right)$ & $\operatorname{MOE}\left(\mathrm{N} / \mathrm{mm}^{2}\right)$ & $\mathrm{CS}\left(\mathrm{N} / \mathrm{mm}^{2}\right)$ \\
\hline \multirow{6}{*}{ Scotch pine } & \multirow{3}{*}{ Epoxy } & Control & $0.545(0.022)$ & $95.69(7.34)$ & $10537(758)$ & $46.59(3.57)$ \\
\hline & & $2+1$ & $0.611(0.024)$ & 87.73 (8.46) & 10019 (684) & $40.29(3.72)$ \\
\hline & & $3+2$ & $0.660(0.025)$ & $89.51(8.51)$ & 9598 (724) & $38.25(3.16)$ \\
\hline & \multirow{4}{*}{ Polyester } & Control & $0.545(0.022)$ & 95.69 (7.34) & $10537(758)$ & $46.59(3.57)$ \\
\hline & & $2+1$ & $0.636(0.022)$ & $94.75(7.31)$ & 9827 (636) & $40.57(3.29)$ \\
\hline & & $3+2$ & $0.682(0.031)$ & 86.47 (6.98) & 8709 (631) & $37.10(2.51)$ \\
\hline \multirow{6}{*}{ Chestnut } & & Control & $0.438(0.017)$ & $55.61(6.14)$ & $4630(354)$ & $32.24(2.13)$ \\
\hline & \multirow[t]{2}{*}{ Epoxy } & $2+1$ & $0.537(0.010)$ & $59.35(5.71)$ & 4659 (265) & 31.34 (1.57) \\
\hline & & $3+2$ & $0.614(0.007)$ & 61.34 (3.59) & 4760 (169) & $31.09(1.22)$ \\
\hline & \multirow{3}{*}{ Polyester } & Control & $0.438(0.017)$ & $55.61(6.14)$ & $4630(354)$ & $32.24(2.13)$ \\
\hline & & $2+1$ & $0.556(0.023)$ & $60.35(7.10)$ & 4887 (439) & $31.25(1.70)$ \\
\hline & & $3+2$ & $0.622(0.018)$ & $55.22(7.31)$ & 4541 (447) & $30.50(1.58)$ \\
\hline
\end{tabular}

Values in parenthesis are standard deviations.

Table 3. Analysis of variance results for density, MOE, MOR, and CS of resin applied wood samples

\begin{tabular}{llllllllll}
\hline \multirow{2}{*}{ Wood species } & \multirow{2}{*}{ Source } & Density & \multicolumn{3}{c}{ MOR } & & MOE & \multicolumn{2}{c}{ CS } \\
\cline { 2 - 9 } Scotch pine & F-ratio & p-value & F-ratio & p-value & F-ratio & p-value & F-ratio & p-value \\
& Factor A & 4.871 & $0.032^{*}$ & 0.372 & - & 3.365 & 0.073 & 0.091 & - \\
& Factor B & 106.472 & $0.000^{*}$ & 4.239 & $0.021^{*}$ & 16.593 & $0.000^{*}$ & 30.541 & $0.000^{*}$ \\
& A*B & 1.241 & 0.299 & 1.884 & 0.164 & 1.889 & 0.163 & 0.207 & - \\
\multirow{2}{*}{ Chestnut } & Factor A & 4.018 & $0.050^{*}$ & 0.933 & - & 0.001 & - & 0.200 & - \\
& Factor B & 496.561 & $0.000^{*}$ & 1.967 & 0.152 & 0.773 & - & 2.819 & 0.071 \\
& A*B & 1.482 & 0.238 & 1.587 & 0.216 & 1.616 & 0.210 & 0.132 & - \\
\hline
\end{tabular}

A: Resin type, B: Number of channel, *:Significant at $95 \%$ confidence level.

Table 4. Duncan's test results for mean values

\begin{tabular}{|c|c|c|c|c|c|c|c|c|c|}
\hline \multirow{2}{*}{ Wood species } & \multirow{2}{*}{ Factor } & \multicolumn{2}{|c|}{ Density $\left(\mathrm{g} / \mathrm{cm}^{3}\right)$} & \multicolumn{2}{|c|}{$\operatorname{MOR}\left(\mathrm{N} / \mathrm{mm}^{2}\right)$} & \multicolumn{2}{|c|}{$\operatorname{MOE}\left(\mathrm{N} / \mathrm{mm}^{2}\right)$} & \multicolumn{2}{|c|}{$\mathrm{CS}\left(\mathrm{N} / \mathrm{mm}^{2}\right)$} \\
\hline & & Mean & $\mathrm{HG}$ & Mean & $\mathrm{HG}$ & Mean & HG & Mean & $\mathrm{HG}$ \\
\hline \multirow{7}{*}{ Scotch pine } & Resin type & & & & & & & & \\
\hline & Epoxy & 0.606 & $\mathrm{~b}$ & 90.98 & $\mathrm{a}$ & 10051 & $\mathrm{a}$ & 41.71 & $\mathrm{a}$ \\
\hline & Polyester & 0.621 & $\mathrm{a}$ & 92.30 & $\mathrm{a}$ & 9691 & a & 41.42 & a \\
\hline & Number of channel & & & & & & & & \\
\hline & Control & 0.545 & $\mathrm{c}$ & 95.69 & $\mathrm{a}$ & 10537 & $\mathrm{a}$ & 46.59 & a \\
\hline & $2+1$ & 0.623 & $\mathrm{~b}$ & 91.24 & $a b$ & 9923 & $\mathrm{~b}$ & 40.43 & $\mathrm{~b}$ \\
\hline & $3+2$ & 0.671 & $\mathrm{a}$ & 87.99 & $\mathrm{~b}$ & 9154 & $\mathrm{c}$ & 37.67 & $\mathrm{c}$ \\
\hline \multirow{7}{*}{ Chestnut } & Resin type & & & & & & & & \\
\hline & Epoxy & 0.529 & $\mathrm{~b}$ & 58.77 & $\mathrm{a}$ & 4683 & $\mathrm{a}$ & 31.56 & $\mathrm{a}$ \\
\hline & Polyester & 0.539 & $\mathrm{a}$ & 57.06 & $\mathrm{a}$ & 4686 & $\mathrm{a}$ & 31.33 & $\mathrm{a}$ \\
\hline & Number of channel & & & & & & & & \\
\hline & Control & 0.438 & c & 55.61 & $\mathrm{a}$ & 4630 & $\mathrm{a}$ & 32.24 & $\mathrm{a}$ \\
\hline & $2+1$ & 0.547 & $\mathrm{~b}$ & 59.85 & a & 4773 & $\mathrm{a}$ & 31.29 & $a b$ \\
\hline & $3+2$ & 0.618 & $\mathrm{a}$ & 58.28 & $\mathrm{a}$ & 4650 & a & 30.80 & $\mathrm{~b}$ \\
\hline
\end{tabular}

HG: Homogeneous group (different letters denote a significant difference).

According to Table 4, the difference between the MOR values of pine and chestnut wood samples at the resin type level was found to be statistically insignificant. The same applies to MOE and CS values. For pine wood samples, the highest MOR, MOE, and CS values at the number of channel level were found to be in the control samples, while the lowest values were obtained in the $3+2$ channels opened samples. The increase in the number of channels caused a decrease in the mechanical strength properties (MOR, MOE, and CS) of the pine wood samples. MOR, MOE, and CS values decreased by $8 \%, 13 \%$, and $19 \%$, respectively, in the $3+2$ channels opened samples compared to control pine wood samples. The increase in the number of channels in the sample is proportional to the amount of resin applied.
Because of this, it may be effective in decreasing the strength values of pine samples in resins which are harder and brittle than wood materials. In the literature, it is reported that the resulting epoxy or polyester resins in liquid form transform into solid with a layer that is a hard, brittle and thermosetting cross-linked structure (Velde, 1992; Miyoshi, 2001; Sönmez \& Budakçı, 2004; Campbell, 2010; Ting et al., 2011). Also, their structures which are prone to brittle (Ersoy, 2001), combustible and fragile, restrict the use of such resins (Güzel, 2016). Hardened resin layer's physical and mechanical properties depend on the functional group types of hardener, cross-link density between resin and hardener, molecular structure and hardening conditions of functional group bonds 
between resin and hardener (Şahmetlioğlu, 2000; Nohales et al., 2006; Montero et al., 2013; Güzel, 2016).

For the chestnut wood samples, no statistically significant difference was observed in terms of both MOR and MOE values between resin applied (channel opened) samples and control (no channel opened) samples (Table 4). It can be said that the chestnut wood samples and the resins exhibited similar behavior in terms of strength properties. In addition, with respect to number of channel, the highest CS value was obtained in the control samples, while the lowest value was found to be in the $3+2$ channels opened samples. The CS value of chestnut wood samples tends to decrease due to the increase in the number of channel. CS value decreased by $4.5 \%$ in the $3+2$ channels opened samples compared to control chestnut wood samples (Table 4).

\section{CONCLUSION}

In this study, the density and the some mechanical strength properties of pine and chestnut wood samples modified with epoxy and polyester resins were investigated. After resin applications, the density values of pine and chestnut samples increased up to $25 \%$ and $42 \%$, respectively, depending on the number of channels. Compared to epoxy resin applied samples, the density increase was higher in polyester resin applied samples.

The effect of the type of resin on all selected mechanical properties (MOR, MOE, and CS) of pine and chestnut wood samples was found to be statistically insignificant. In other words, similar strength values were obtained in both epoxy and polyester resin applied samples.

In pine wood samples with resin applied, the strength values decrease depending on the increase in the number of channels. The MOR, MOE and CS values of these samples decrease by $8 \%, 13 \%, 19 \%$ respectively when compared to the control (untreated) pine samples. In chestnut samples, the effect of the number of channels on the mechanical strength was found to be statistically insignificant.

\section{REFERENCES}

Bulmuş, V. \& Pişkin, E. (2000). Epoksi reçineleri, mühendislik polimerleri, Pagev Yayınları, İstanbul, Türkiye.

Campbell, F.C. (2010). Structural composite materials, ASM international: Materials Park, OH, USA,

Chung, D.D.L. (2010). Composite Materials: Science and Applications, 2nd ed., Springer, Berlin.

Güzel, G. (2016). Epoksi reçinesi-yüksek firın cürufu/yer fistığ kabuğu tozu kompozitlerinin hazırlanması ve özelliklerinin incelenmesi, Yüksek Lisans Tezi, Selçuk Üniversitesi Fen Bilimleri Enstitüsü, Konya, Türkiye, 113s.
Ersoy, H.Y. (2001). Kompozit malzeme, Literatür Yayınları, No: 66, İstanbul, Türkiye.

ISO/DIS 13061-17. (2015). Test methods for small clear wood specimens-determination of ultimate stress in compression parallel to grain. International Organization for Standardization, Switzerland.

Kaw, A.K. (2005). Mechanics of composite materials. CRC Press, New York, USA.

Miyoshi, K. (2001). Solid lubrication fundamentals and applications, CRC Press, New York, USA, p. 266.

Montero, B., Serra, A., Ramírez, C. \& Ramis, X. (2013). Epoxy/anhydride networks modified with polyhedral oligomeric silsesquioxanes. Polymer Composites, 34(1), 96-108.

Nohales, A., Solar, L., Porcar, I., Vallo, C.I. \& Gómez, C.M. (2006). Morphology, flexural, and thermal properties of sepiolite modified epoxy resins with different curing agents. European Polymer Journal, 42(11), 3093-3101.

Seyhan, A.T., Gojny, F.H., Tanoğlu, M. \& Schulte, K. (2007). Critical aspects related to processing of carbon nanotube/unsaturated thermoset polyester nanocomposites. European Polymer Journal, 43(2), 374-379.

Sezgin, H. (2018). Investigation and enhancement of the mechnanical properties of the fabric reinforced hybrid composites. Ph.D. Thesis, İstanbul Technical University, Institute of Science and Technology, İstanbul, Turkey, p.189.

Sönmez, A. \& Budakçı, M. (2004). Protective layers and paint/varnish systems, finishing on woodworking II., Gazi University, Technical Education Faculty, Sevgi Ofset, Ankara, Turkey.

Şahmetlioğlu, E. (2000). Epoksi reçinelerinin üretimi bağlayıcı ve yapıştırıcı olarak kullanımının araştırılması. Yüksek Lisans Tezi, Niğde Üniversitesi Fen Bilimleri Enstitüsü, Niğde, Türkiye, 116s.

Ting, T.H., Wang, T.M., Yang, S.F., Sun, K.S. \& Lee, W.C. (2011). Effect of the water quenched slag-epoxy resin composite on microwave absorbing properties. Journal of the Chinese Chemical Society, 58(1), 83-89.

TS 2470. (1976). Sampling methods and general requirements for physical and mechanical tests in wood. Turkish Standards Institution, Ankara, Turkey.

TS 2471. (1976). Determination of moisture content for physical and mechanical tests in wood. Turkish Standards Institution, Ankara, Turkey.

TS 2472. (1976). Determination of density for physical and mechanical tests in wood. Turkish Standards Institution, Ankara, Turkey. 
TS 2474. (1976). Wood-determination of ultimate strength in static bending. Turkish Standards Institution, Ankara, Turkey.

Velde, B. (1992). Introduction to clay minerals, chemistry, origins, uses and environmental significane. 1 th Edition, Chapman \& Hall Inc., London, Great Britain, pp. 10-15.

Web-1. http:// www.gncahsap.com, (22 June 2018).

\section{*Corresponding author's:}

\section{Hüseyin PELİT}

Duzce University, Faculty of Technology, 81620, Duzce,

Turkey.

E-mail : huseyinpelit@duzce.edu.tr

ORCID : https://orcid.org/0000-0002-5706-473X

Phone : +90 (380) $5421133 / 2123$

Fax : $+90(380) 5421134$ 